\title{
Polymorphic organization in a planktonic graptoloid (Hemichordata: Pterobranchia) colony of Late Ordovician age
}

\author{
JAN A. ZALASIEWICZ $\ddagger^{*}$, ALEX PAGE $\ddagger$ R. BARRIE RICKARDS $\dagger$, \\ MARK WILLIAMS $\ddagger$, PHILIP R. WILBY $\ddagger$, MICHAEL P. A. HOWE \\ \& ANDREA M. SNELLING
}

$\ddagger$ Department of Geology, University of Leicester, Leicester LE1 7RH, UK

§Department of Earth Sciences, University of Cambridge, Cambridge CB2 3EQ, UK

\British Geological Survey, Keyworth, Nottingham NG12 5GG, UK

(Received 4 October 2011; accepted 27 April 2012; first published online 9 August 2012)

\begin{abstract}
Graptolites are common fossils in Early Palaeozoic strata, but little is known of their softpart anatomy. However, we report a long-overlooked specimen of Dicranograptus aff. ramosus from Late Ordovician strata of southern Scotland that preserves a strongly polymorphic, recalcitrant, organicwalled network hitherto unseen in graptoloid graptolites. This network displays three morphologies: proximally, a strap-like pattern, likely of flattened tubes; these transform distally into isolated, hourglass-shaped structures; then, yet more distally, revert to a (simpler) strap-like pattern. The network most likely represents a stolon-like system, hitherto unknown in graptoloids, that connected individual zooids. Its alternative interpretation, as colonial xenobionts that infested a graptoloid colony and mimicked its architecture, is considered less likely on taphonomic and palaeobiological grounds. Such polymorphism is not known in non-graptolite pterobranchs, which are less diverse and morphologically more conservative: a division of labour between graptoloid zooids for such functions as feeding, breeding and rhabdosome construction may have been the key to their remarkable evolutionary success.

Keywords: polymorphism, graptolite, zooplankton, Ordovician, soft anatomy, xenobionts.
\end{abstract}

\section{Introduction}

The Palaeozoic graptolites (Pterobranchia, Hemichordata) were colonial organisms of considerable morphological and taxonomic diversity. Graptoloid graptolites occur as abundant fossils in rocks of Ordovician to Devonian age and are the most commonly preserved component of the Early Palaeozoic macrozooplankton. Their organic-walled rhabdosomes (dwelling structures) were built and inhabited by colonies of zooids. Graptolite rhabdosomes are widespread in the mudrocks that were laid down on the intermittently anoxic sea floors of that time (Rickards, 1975; Palmer \& Rickards, 1991; Underwood, 1992; Briggs et al. 1995; Page et al. 2008; Zalasiewicz et al. 2009).

Graptolites are known almost exclusively from their rhabdosomes, rather than remains of their zooids, despite their long history of study (Elles \& Wood, 19011918; Rushton, 2001) and their burial in depositional environments that may favour organic preservation (Butterfield, 1990; Briggs, 2003; Page et al. 2008). This is owing to the rapid decay of their zooids (Briggs et al. 1995) and the lengthy post-mortem drift experienced by the planktonic colonies prior to their arrival at the sea floor (Underwood, 1992). Thus, their internal anatomy has hitherto only been evident from scant, incomplete and ambiguous evidence (Rickards, Partridge \& Banks, 1991; Bjerreskov, 1994; Briggs et al. 1995; Loydell,

\footnotetext{
*Author for correspondence: jaz1@le.ac.uk $\dagger$ Deceased 2009
}

Orr \& Kearns, 2004), though a well-preserved (likely benthic) pterobranch has recently been recognized from the Lower Cambrian Chengjiang deposit (Hou et al. 2011); morphologically this specimen appears similar to, if larger than, modern pterobranchs.

The zooid anatomy and internal organization of the planktonic graptolites (graptoloids) has mainly been reconstructed by analogy with their extant relative Rhabdopleura, a pterobranch hemichordate (Kozłowski, 1948; Bulman, 1970; Rickards, 1975; Bates, 1987; Crowther \& Rickards, 1977; Palmer \& Rickards, 1991; Rigby \& Sudbury, 1995; Melchin \& DeMont, 1995; Briggs et al. 1995). Like Rhabdopleura, graptolites are held to be animal architects, their rhabdosome being built of collagen actively secreted by the combined activities of many individual zooids within the colony (Palmer \& Rickards, 1991; Crowther \& Rickards, 1977; Rigby \& Sudbury, 1995). However, the graptolite rhabdosome shows a markedly more complex morphology than is seen in modern pterobranchs, and some workers have questioned the similarity of their respective soft anatomies (Bates, 1987; Bates \& Kirk, 1987, 1991; Melchin \& DeMont, 1995; Loydell, Orr \& Kearns, 2004) and mode of skeletal construction (Bates \& Kirk, 1987, 1991). The internal zooidal architecture of graptoloid colonies is almost entirely unknown. As a common canal has not previously been identified in graptoloids, it is unclear if they were true colonies with their zooids connected, or if these colonies were unconnected tube-sharing aggregates like some examples of the 


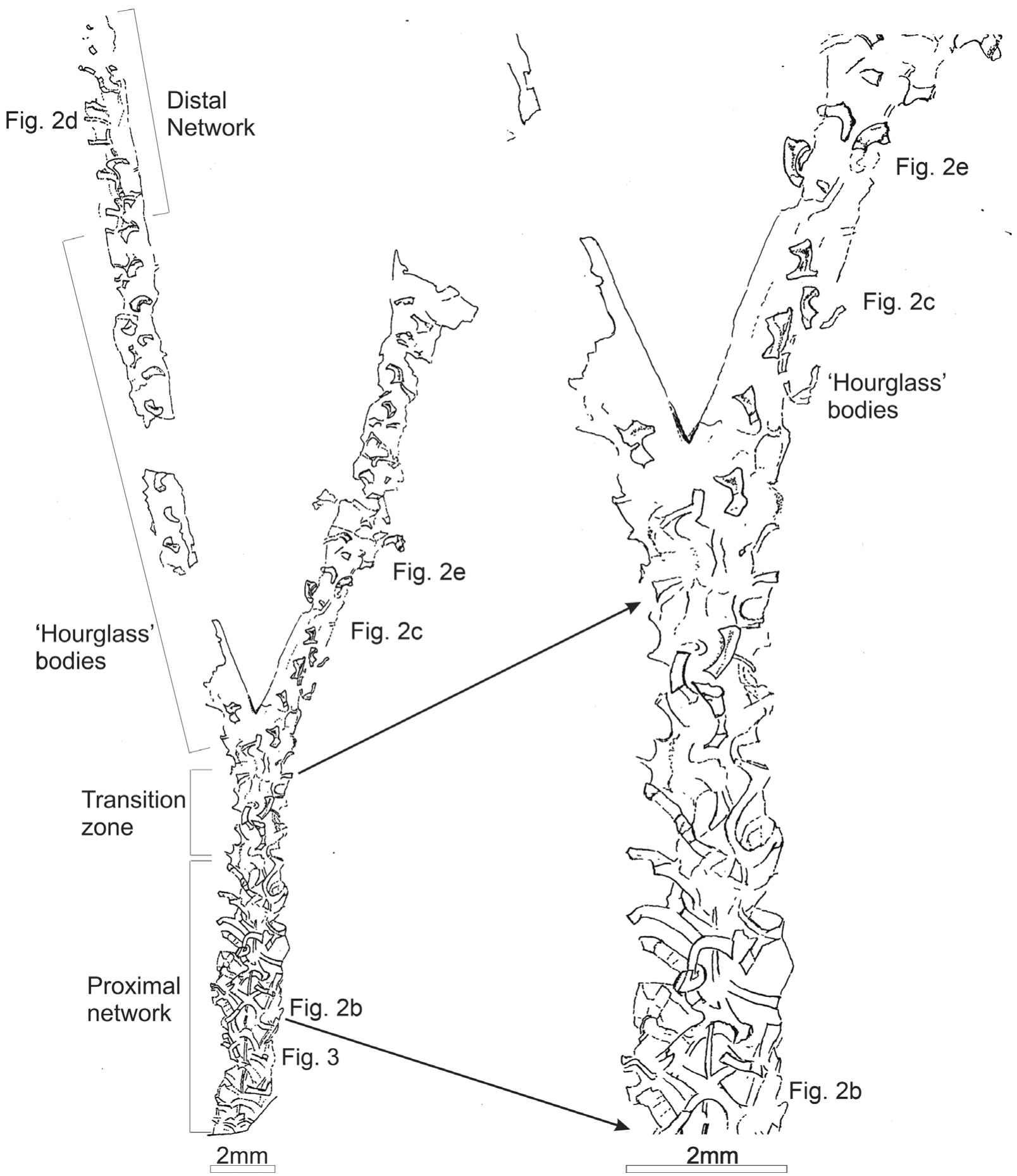

Figure 1. Camera lucida drawing of $D$. aff. ramosus showing rhabdosome outline and the polymorphic network.

pterobranch Cephalodiscus (Rickards, Partridge \& Banks, 1991). Consequently, and in the absence of convincing examples of soft-part preservation, the true nature of the graptolite zooid has remained elusive.

Here, we describe a unique specimen of the graptolite Dicranograptus aff. ramosus with a preserved organic network hitherto unknown in graptoloid graptolites (Figs 1,2). This problematic structure could plausibly reflect either (a) a fundamental aspect of graptoloid anatomy not normally seen in their fossil record; or (b) extensive colonization of these rhabdosomes by an unidentified organic-walled xenobiont. We argue on both palaeobiological and preservational grounds that this network most likely reflects the preserved stolon in a graptoloid taxon that had evolved an abnormally recalcitrant pectocaulus; hence, this likely represents the first-known direct evidence of the zooidal architecture of graptoloids.

\section{Methods}

Graptolite fossils are often difficult to image as they are typically preserved with low relief and may be of similar colour to the host rock. We have 

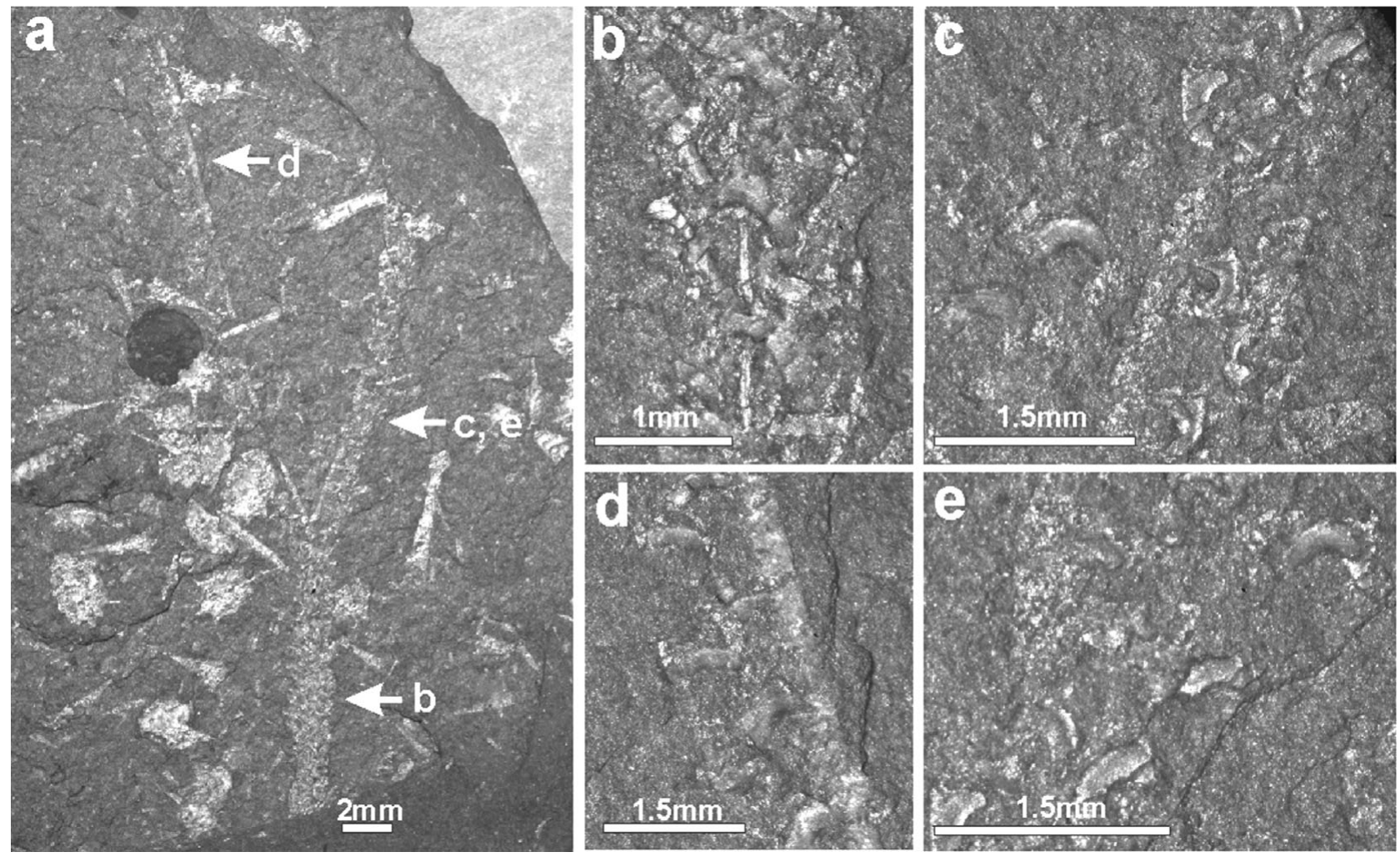

Figure 2. Photographs of GSE 5495, Glenkiln Shales Formation (gracilis graptolite Biozone) from Carrifran Burn, near Moffat, Scotland, UK, showing polymorphism in the network-bearing graptoloid (a) D. aff ramosus preserved alongside other graptolites and a brachiopod. For position of photographs (b-e) on the graptolite see Figure 1; (b) complex, strap-like network cross-cutting the median septum in the biserial portion; (c) hourglass-shaped architecture on the 'east' uniserial branch crossed by the second specimen of $D$. aff ramosus on the rock slab; (d) reversion to strap-like network in the distal part of the 'west' uniserial branch; (e) hourglass-shaped architecture slightly more distal to 'd' on the 'east' uniserial branch.

photographed the graptolites immersed in alcohol using a combination of low-angle and ring lighting and a Canon 5D digital single-lens reflex camera attached to a Leitz Aristophot (Fig. 2), and we have also made a camera lucida drawing using a Wild Heerbrugg M5 stereomicroscope (Fig. 1). Back-scattered electron micrographs (BSEMs) were taken (Fig. 3) and phases identified using EDX in a LEO 435VP scanning electron microscope (ESEM), equipped with an Oxford ISIS energy-dispersive X-ray analyser (EDX). The specimens were also X-rayed in a Muller $150 \mathrm{kV}$ CP Be unit, CT-scanned by a Metris XTH 225CT system and photographed under ultraviolet light, though none of these approaches yielded any significant additional information.

\section{Palaeontology}

The graptolite Dicranograptus aff. ramosus preserves a semi-continuous network of strap- and hourglassshaped bodies (for network morphologies see Figs 1, 2) not apparent from other graptolites on this slab or elsewhere. This taxon agrees well with the overall morphology of Dicranograptus ramosus (Hall), but as the length of its biserial portion cannot be fully determined, its affinity cannot be confidently diagnosed. The preserved network also differentiates it from typical forms.

\section{3.a. Material}

One near-complete specimen of Dicranograptus aff. ramosus, and a poorly preserved fragment, are preserved on one of two surviving syntype blocks of Rogercooperia phylloides (Elles \& Wood). The block (GSE 5495) has been held for over a century in the Museum Reference collection of the British Geological Survey, Keyworth, Nottingham, UK, and graptolites from it have been figured in several papers (e.g. see Sherwin \& Rickards, 2000); the dicranograptid material on the block, though, has not been figured previously, to our knowledge. The block was collected from an exposure of the Glenkiln Shales Formation of Nemagraptus gracilis graptolite Biozone age (Sandbian Stage, Late Ordovician) in Carrifran Burn, a valley 6.5 miles $(10.5 \mathrm{~km})$ NE of Moffat, Scotland, UK.

\section{3.b. Geological setting and preservation}

The specimens come from a typical part of the Glenkiln Shales Formation. These deep-water mudstones are not typically associated with the preservation of soft tissues or of weakly sclerotized cuticle (cf. Butterfield, 




Figure 3. Preservation of the $D$. aff. ramosus network illustrated with a photomicrograph, BSEM image. For position on whole graptolite specimen see Figure 1. Areas where organic carbon has flaked away reveal metamorphic chlorite templates coating the network and rhabdosome. (a) Carbonized nema; (b) carbonized 'stolon' of meshwork; (c) clay mineral template of stolon meshwork (original carbon flaked away); (d) fragmentary periderm of graptolite rhabdosome.

1990). The preservation of the graptolite and associated brachiopods and conodonts on the slab is typical for the lithofacies, save for the occurrence of the unique organic network in the specimens of $D$. aff. ramosus. The specimens, like all other graptolites on the slab, are flattened on a single sedimentary lamina. They are preserved as organic compressions associated with authigenic phyllosilicates (cf. Page et al. 2008). Their periderm appears thinner than that of the other graptolites, though this is not atypical of dicranograptid preservation. The network itself has greater relief than the periderm, and is distinctly more reflective. As with the periderm, it is preserved as organic carbon associated with phyllosilicates. The composition of the phyllosilicates associated with the network does not appear to differ from those associated with the periderm of $D$. aff. ramosus or the other graptolites. The preservation of the material is thus generally typical of carbonaceous graptolite fossils in low-grade metamorphic mudrocks.

\section{3.c. Description}

The most complete specimen of $D$. aff. ramosus displays both the rhabdosome's biserial portion, comprising two rows of thecae, and its more distal uniserial branches, both of which have a single row of thecae. Approximate thecal outlines can be determined along part of the biserial portion. The near-complete specimen reveals an internal network in three markedly different patterns: one in the proximal biserial part; another more distally on the biserial part which continues to the proximal part of the uniserial stipes; and a third in the distal-most preserved uniserial part of the rhabdosome.

The proximal c. $8 \mathrm{~mm}$ of the biserial portion (Figs 1, 2a, b) shows a complex interwoven network of strap-shaped structures, presumed to be diagenetically flattened tubes. From 'X-shaped' axial 'branch nodes', spaced at $c .1 \mathrm{~mm}$ intervals (Figs 1,2b), rows of straps branch off diagonally outwards, terminating at or near the edge of the rhabdosome. The pattern of these straps appears different on the left and right hand sides of the rhabdosome. On the right hand ('east') side, outwardsextending straps at $c .1 \mathrm{~mm}$ intervals are crossed by straps trending more nearly parallel to the rhabdosome axis. On the left hand ('west') side, straps trending at c. $45^{\circ}$ to the rhabdosome axis are spaced at c. $0.5 \mathrm{~mm}$ intervals: this is a similar overall packing density to the tubes on the opposite side, and approximates to double the thecal spacing of the graptolite.

About $8 \mathrm{~mm}$ from the observed proximal-most part of the specimen, the network pattern changes, its 'plaited' interweaving nature transforming distally over some $2-3 \mathrm{~mm}$. In the transitional zone (Fig. 1) there are apparently isolated structures that are broader, curved and constricted in their central part and wider distally than proximally (Figs 1, 2c, e). They resemble a curved or bent hourglass in outline. These segments have more conspicuous relief than seen elsewhere in 
the network and typically possess a shallow central longitudinal (concave) fold in their broader, distal part. Their proximal and distal ends are well defined, straight or slightly concave and they too are considered flattened tube segments.

This pattern is then accentuated (the segments becoming shorter and stouter) and is maintained throughout the distal part of the biserial portion and along most of the length of the uniserial branches. The 'curved hourglass' structures are isolated, and are mostly evenly spaced in an 'en échelon' pattern with a c. $1 \mathrm{~mm}$ interval (i.e. half the spacing of the straps in the plaited region and thus one per theca).

Lastly, in the distal part of the 'west' branch (Fig. 2a, d), this pattern gives way to one reminiscent of, but not identical to, that of the main part of the biserial portion. A longitudinal strap, c. $0.1 \mathrm{~mm}$ wide, initially runs subcentrally within the branch and then steps sharply to run near to the 'east' side. From this extend parallel-sided straps, c. $0.2 \mathrm{~mm}$ across, which run perpendicular to the axis and trend mostly to the 'west' with one or two to the 'east'. As with the more proximal network, the straps are spaced overall at c. $0.5 \mathrm{~mm}$ intervals (though the spacing in detail is more irregular), suggesting that there are again two per theca.

A poorly preserved portion of a second specimen is represented by another line of 'curved hourglass' structures that crosses the uniserial branches of the first specimen (Fig. 2c, e).

\section{Interpretation of the network}

The network preserved in D. aff. ramosus is unlike any structure previously reported from graptoloid graptolites, making its interpretation potentially highly informative but problematic. The network occurs in two specimens of $D$. aff. ramosus but not in any other graptolite on the slab, suggesting that it represents some fundamental part of this taxon's anatomy, life history or taphonomy.

It is unclear how distortion in compaction could have created the appearance of a polymorphic network. Experimental and observational work on the flattening of carbonaceous fossils (including graptolites and organic tubes) show that simple, cylindrical bodies flatten uniformly to form parallel-sided compressions, whereas more complex three-dimensional bodies still, reasonably faithfully, portray the body's outline (Sudbury, 1958; Briggs \& Williams, 1981). The hourglassshaped structures of the network are significantly more three-dimensional than the strap-like portion, suggesting that these originally had a more complex morphology, while the strap-like structures likely represent flattened simple tubes. Thus, the restriction of the hourglass-shaped structures to the central portion of the rhabdosome (Figs 1, 2a, c, e) genuinely reflects their disposition in life.

To our knowledge no polymorphic network or comparable structure has ever been reported in graptolites or pterobranchs, though perhaps one might have been expected, based on models of graptolite biology and given the presence of a stolon in dendroid graptolites. The network differs substantially from putative examples of graptolite eggs and embryos (Kozłowski, 1948; Bulman \& Rickards, 1966), which occur sporadically as isolated bodies in certain thecae. Nor can the network reasonably be interpreted as a vestige of dicranograptid thecal architecture: it is noticeably more reflective than normal thecal periderm and displays a markedly greater relief (Fig. 2be). Moreover, the variation in network morphology is unlike any aspect of a typical dicranograptid rhabdosome (cf. Bulman, 1944), suggesting it cannot be an artefact of differential decay. Nor does the network display any feature that can be interpreted as pterobranch zooids, with no vestige of tripartite construction, lophophore or secretory disc apparent (cf. Dilly, 1972; Crowther \& Rickards, 1977; Palmer \& Rickards, 1991; Rigby \& Sudbury, 1995; Melchin \& DeMont, 1995; Hou et al. 2011). So, whilst the network is restricted to D. aff. ramosus, it cannot easily be interpreted using any of the above analogues, indicating it represents an intrinsic, yet hitherto unknown, aspect of this taxon's palaeobiology.

In interpreting this enigmatic fossil, we consider taphonomic evidence (cf. Donoghue \& Purnell, 2009) as to the network's composition before comparing the preserved structures with two contrasting interpretive models, respectively that the preserved network in $D$. aff. ramosus represents either (a) extensive colonization by xenobionts, or (b) a previously unknown part of the colony's internal zooidal architecture.

\section{4.a. Taphonomic considerations}

Both the graptolite periderm and the enigmatic network are preserved as a carbonaceous compression associated with a phyllosilicate template (Fig. 3), as is typical for graptolites and other organic compressions in lowgrade metamorphic mudrocks (Palmer \& Rickards, 1991; Underwood, 1992; Page et al. 2008, 2010). The organic preservation of 'soft-bodied' animals is heavily biased towards the preservation of nonliving cuticular anatomy, with living, cellular anatomy rarely forming organic fossils (Butterfield, 2003). For example, scolecodonts, the heavily sclerotized teeth of polychaete worms, are significantly more decayresistant than the animal's weakly sclerotized body cuticle (Briggs \& Kear, 1993), and overwhelmingly dominate the fossil record of the group (Sutton et al. 2001). Thus, the D. aff. ramosus network likely represents the preservation of a heavily sclerotized exoskeletal secretion rather than cellular anatomy.

\section{4.b. Xenobiont hypothesis}

The network could conceivably represent colonization of the rhabdosome by a xenobiont. Post-mortem colonization seems unlikely given the anoxic bottom water conditions that characterized the deposition 
of the Glenkiln Shales Formation and the hostspecificity of the network. In vivo colonization is more likely, presumably reflecting some aspect of $D$. aff. ramosus's synecology that was particularly amenable to epibionts. Potentially appropriate parasitic or commensal epibionts are discussed in turn below.

\section{4.b.1. Epibionts in pterobranchs}

Graptolite parasites (sensu Bates \& Loydell, 2000) are known from a range of Ordovician and Silurian taxa (though epibionts have not to our knowledge been reported from other pterobranchs). These graptolite parasites represent the in vivo infestation of the external walls of the graptolite rhabdosome by an unknown organism or organisms, and are preserved by 'blisters' of cortical tissue secreted around the parasite by the graptolite. These epizoans were clearly injurious to the host colony as no parasitized individual is known to have grown beyond a few thecal pairs (Jackson, 1971; Bates \& Loydell, 2000) and extensively parasitized forms show clear teratologies, in the form of disruption of growth patterns. Such parasites are only known from three-dimensionally preserved acid-isolated material. Comparable structures would be difficult to see in flattened specimens: the delicate layer of cortical tissue that surrounds the site of infestation is much thinner than the fusellar and cortical material that compose the rhabdosome wall, and thin films of cortical fabric are prone to decay and compactional distortion (see discussions of Hallograptus scopulae and the Climacograptus wilsoni vesicle in Page et al. 2009).

More enigmatically, Legrand (1978, 1979, 1986) has described complex, tubular structures within the Early Silurian graptolite Diplograptus fezzanensis from the Algerian Sahara. These are straight, slender (c. $0.1 \mathrm{~mm}$ ) with repeating cup-like structures and denticles, and may represent some kind of symbiotic or parasitic organism.

The $D$. aff. ramosus network differs markedly from these infestations. Not only is it better preserved than the rhabdosome walls (Fig. 2b-e), but it also occurs in a fully-grown specimen displaying no obvious teratologies. There is no evidence to suggest it extended beyond the walls of the rhabdosome, yet it seems unlikely that it could have been sustained on the inside of the colony's exoskeleton. Such intense infestation within the colony would have impeded the growth and function of the zooids that fed the graptolite and kept it afloat. So, rather than forming on the inside of the colony, or externally like the parasites described above, any potential epizoan forming this network must have been commensal or symbiotic, secreting the recalcitrant structure it inhabited on the external walls of the rhabdosome.

\section{4.b.2. Epibionts in other colonial organisms}

Bryozoans host a variety of epibionts from parasitic to symbiotic, providing a useful interpretive model for the xenobiont hypothesis. These epizoans include other bryozoans, hydroids, sessile polychaetes and tunicates; some of these colonial epizoans mimic colonial structure to some extent (Stebbing, 1970), whilst others dwell within skeletal structures secreted by the host (McKinney, 2009). The latter possibility can be ruled out as the network does not conform to typical dicranograptid architecture. As such we need only concern ourselves with the histology and anatomy of tube-dwelling epizoans.

The bifurcating network of $D$. aff. ramosus is unlike any known priapulid tube. Serpulids and pogonophores (phylum Polychaeta) have un-branching tubes. The ascidians (phylum Tunicata), however, are both encrusting and colonial, as are hydroids and bryozoans. All these taxa have planktonic larvae, and so have the potential to infest a graptoloid graptolite. However, no tunicates, hydroids or Palaeozoic bryozoans display polymorphism comparable with that seen in this network. So, as dendroid graptoloids are the only polymorphic colonial animal known to have evolved prior to the cheilostome bryozoans (Carter, Gordon \& Gardner, 2010), one has to consider a graptolitic origin for the network.

Taphonomic analysis suggests that the network was composed of a collagen-like biopolymer, like that of graptolites. Page et al. (2008) showed that different clay minerals develop on different biopolymers during low-grade metamorphism of graptolitic mudrocks. EDX analysis showed that the metamorphic clay minerals associated with the $D$. aff. ramosus network are indistinguishable from those associated with its rhabdosome, suggesting that both are of the same composition (Fig. 3). And, as there is no evidence of graptolite xenobionts having ever encrusted other graptolites, the $D$. aff. ramosus network seems most reasonably considered as recording a hitherto unknown part of graptoloid anatomy.

\section{4.c. Stolon hypothesis}

The stolon - the common canal that links pterobranch zooids in a colony - has not been recorded in the fossil record of graptoloid graptoloids. The stolon of the fossil dendroid graptolite Rhabdopleura is acuticular in juvenile zooids (the gymnocaulus condition) and later covered by the sclerotized pectocaulus (Urbanek \& Dilly, 2000). This structure can be well preserved in fossil rhabdopleurans, and the dendroid graptolite stolon was also readily fossilized (Chapman, Durman \& Rickards, 1993; Rickards, Partridge \& Banks, 1991). The extant pterobranch Cephalodiscus lacks a stolon and its zooids are not always connected (Rickards, Partridge \& Banks, 1991). With a lack of information from the fossil record concerning whether graptoloid zooids were connected or not (Briggs et al. 1995), it is unclear whether their stolon was absent, atrophied or acuticular. One possible interpretation of the $D$. aff. ramosus network is that it represents a stolon-like connective structure. This scenario posits that, rather 
than losing their stolon, graptoloids evolved a poorly sclerotized or acuticular common canal, with $D$. aff. ramosus representing a unique taxon that secondarily evolved a robust and recalcitrant cuticle surrounding its common canal.

If the $D$. aff. ramosus network was truly stolon-like, there would be little taphonomic reason for its nonpreservation. The network displays a more complex morphology than is seen in examples of fossilized pterobranch stolons, which have only simple straight or slightly curved outlines (e.g. Bulman, 1970; Rickards, Partridge \& Banks, 1991; Maletz, Steiner \& Fatka, 2005). Nonetheless, it both cross-cuts and is cross-cut by the nema/median septum, and does not protrude beyond the rhabdosome walls (Figs 1, 2b), both of which are consistent with it being an internal rather than encrusting structure (cf. Bates \& Loydell, 2000). This suggests that $D$. aff. ramosus was either cryptoseptate or only partially septate with a polymorphic network formed of criss-crossing and in places flared tubes weaving in between thecae along the colony's whole length.

It may represent either an evolutionary novelty in a rare new taxon or a pathology/teratology involving sclerotization of the normally soft stolon system. As it is present in more than one specimen, we consider the former interpretation more likely.

\section{4.d. Interpretation of the preserved network}

If the network represents a stolon, its structure provides information concerning the zooid arrangement of $D$. aff. ramosus (and perhaps other graptoloids). Though the divergently broadening portions of the network are reminiscent of the putative zooids of the Cambrian pterobranch Rhabdopleura obuti Durman \& Sennikov (1991, text-fig. 1), there is no trace of a lophophorelike feeding apparatus nor of a secretory disc (see Bulman, 1970; Rickards, 1975; Crowther \& Rickards, 1977; Rigby \& Sudbury, 1995; Melchin \& DeMont, 1995; Hou et al. 2011). Rather, these structures preserve the recalcitrant sheath that covered a common canal connecting the zooids. From this we see the internal architecture of a graptolite colony, reflecting the organization of the zooids, and may infer the spacing of the zooids (seemingly packed two per theca in places) and changes in soft-tissue anatomy along the colony.

\section{Discussion and conclusions}

This specimen, on balance, seems to provide evidence of the organization of the zooids that inhabited the colony, though the zooids themselves are not preserved. Thus, analysis of the zooid system in graptoloids need no longer solely be based on analogy with extant pterobranchs (e.g. Bulman, 1970; Rickards, 1975; Bates, 1987; Bates \& Kirk, 1987; Palmer \& Rickards, 1991; Dilly, 1993; Melchin \& DeMont, 1995; Rigby
\& Sudbury, 1995; Briggs et al. 1995; Loydell, Orr \& Kearns, 2004).

The fossil record of such graptolite soft parts is meagre (Rickards, Partridge \& Banks, 1991; Underwood, 1992; Palmer \& Rickards, 1991; Bjerreskov, 1994; Briggs et al. 1995; Loydell, Orr \& Kearns, 2004). Putative soft parts have only previously been recorded in graptolites from three localities (Rickards, Partridge \& Banks, 1991; Bjerreskov, 1994; Loydell, Orr \& Kearns, 2004) and in these the preservation is incomplete and ambiguous. Pyritized bodies, inferred to be zooids, have been found in the Early Ordovician dendroid Psigraptus jacksoni (Rickards, Partridge \& Banks, 1991). Strap-like organic fragments from the Silurian graptoloids Rastrites geinitzii and Neolagarograptus? sp. have been interpreted as contractile stalks of zooids (Loydell, Orr \& Kearns, 2004), and pyrite blebs that 'may represent the remnants of bodies or stalks of zooids' occur in a single specimen of the Silurian graptoloid Monoclimacis sp. (Bjerreskov, 1994). All told, these few indistinct remains tell us little of zooid organization.

In contrast, the recalcitrant stolon-like network we infer for $D$. aff. ramosus is preserved along the full length of at least the most complete specimen in this study, and shares attributes in common with the softbodied architecture of the extant pterobranchs as well as other graptolites. In Rhabdopleura fleshy, acuticular zooids are linked by a highly decay-resistant cuticular stolon (Bulman \& Rickards, 1966; Briggs et al. 1995). Rhabdopleuran 'dormant' zooids may possess a cuticle themselves too (Stebbing, 1970; Dilly, 1975); the same is true of aestivated graptoblasts in crustoid graptolites (Kozłowski, 1962; Urbanek, 1962). In the largely benthic dendroids, the stolon is likewise recalcitrant and commonly fossilized (Briggs et al. 1995; Loydell, Orr \& Kearns, 2004). In both fossil and extant Rhabdopleura and in non-graptoloid graptolites, the stolon forms a simple branching tube, which displays little along-rhabdosome variation and barely diverges from being parallel-sided along its whole length. This is in stark contrast with the condition in $D$. aff. ramosus. Firstly, only the distal part of the west uniserial branch shows similarity to the classic 'Wiman' pattern of dendroid graptolites, in which zooidal tubes branch off from a central stolon (Bulman, 1970). Instead, the biserial portion shows a more complex interweaving pattern (Figs 1, 2b), where tube segments cross from one side of the rhabdosome to the other. Moreover, the $D$. aff. ramosus network shows a marked morphological variation along the rhabdosome's length.

The striking morphological variation in the stolonlike $D$. aff. ramosus network necessarily reflects the colony's zooidal architecture. The proximal portion has its straps packed twice as closely as the 'hourglasses' in the more distal biserial part of the rhabdosome (Figs 1, 2). Assuming both were connected to zooids, there would have been two zooids per thecae in the proximal part of the biserial portion and only one per thecae more distally. The variation in the width and packing 
between 'hourglasses' and 'straps' would be consistent with zooids being consistently bigger in the central part of the rhabdosome. Interestingly, independent estimates of zooid size in a single specimen produce two very different results (Rigby \& Sudbury, 1995): one suggests small zooids; the other suggests very large zooids. The size difference between autothecae and bithecae in dendroids has also been used to argue for variation in zooid size (Kozłowski, 1948; Bulman, 1970; Rickards, 1975; Rickards, Partridge \& Banks, 1991), although this is not expressed in the morphology of their stolon. Having two zooids per thecae may be a legacy of the progressive reduction in the number of (smaller) bithecae in the dendroidgraptoloid divergence (Rickards, 1975; Palmer \& Rickards, 1991); the variation in network packing may also reflect a bitheca/autotheca-like differentiation in $D$. aff. ramosus.

The along-rhabdosome variation in network morphology exhibited in $D$. aff. ramosus may not be easily interpreted as reflecting ontogenetic changes in zooid morphology. In Rhabdopleura individual zooids grow from small buds into larger adults. Male, female and asexual zooids may be present in any one colony (Sato, 2008). These zooids are not notably polymorphic and individual creeping tubes may be filled by several successive generations such that parent-offspring relationships cannot be determined (Rigby \& Sudbury, 1995; Dilly, 1972; Sato, 2008). Though dormant zooids are clearly distinguished based on their morphology, the male, female and juvenile zooids are randomly positioned within the colony (Stebbing, 1970; Dilly, 1972, 1975; Sato, 2008) as are the aestivated graptoblasts of crustoid graptolites (Kozłowski, 1962; Urbanek, 1962). As the rhabdosome-long morphological variation in the $D$. aff. ramosus network is expressed in a heavily sclerotized, extra-cellular secretion, it likely represents a permanent or semi-permanent structure that may have placed significant constraints on functional morphology.

Therefore, rather than representing an ontogenetic or sexual polymorphism in zooidal architecture, it appears more likely that the zooids of $D$. aff. ramosus had differentiated functional morphology. Such semipermanent variation in zooid functional morphology is unknown in extant pterobranchs. Authothecae and bithecae are present throughout the dendroid rhabdosome but cannot readily be differentiated from the morphology of the stolon, indicating that any differentiation in zooid type was less clearly partitioned in dendroids than in D. aff. ramosus. In Rhabdopleura, zooids are generalists with each equally equipped to feed, breed or build its coenecium - a structure equivalent to the graptolite rhabdosome (Stebbing, 1970; Dilly, 1972, 1975; Rickards, 1975; Crowther \& Rickards, 1977). Graptoloid zooids must in addition have been able to provide the buoyancy required for existence in the plankton (Bates, 1987; Melchin \& DeMont, 1995), and some workers have argued that a generalist Rhabdopleura-like zooid could not have constructed the intricate morphologies of graptoloid rhabdosomes (Bates \& Kirk, 1987, 1991).

Thus the strap- and hourglass-shaped zooids within the colony we describe may provide evidence for different functional morphologies, distinguishing zooids associated with feeding, swimming, breeding and colony-building. The latter forms were most likely positioned towards the rhabdosome's actively growing distal extremity and represented by the Wimanpattern strap-like network. Other morphotypes may be represented by the complex-branching, close-packed 'straps' of the proximal portion, and the hourglassshape morphs in the rhabdosome's centre.

It is striking that the variation between the different 'stolon' morphotypes does not coincide closely either with gross rhabdosomal morphology or with the subtle along-rhabdosome change in dicranograptid thecal morphology. Later Silurian monograptids can show striking change in thecal style between proximal and distal thecae (e.g. Hutt, 1974; Zalasiewicz \& Howe, 2003) that might reflect functional differentiation. On the evidence of the graptolite we describe here, close correspondence between hard-part and soft-part morphology cannot be assumed.

Such polymorphism and functional differentiation is not apparent in other Palaeozoic colonial organisms, and is not seen again in the fossil record until the evolution of cheilostome bryozoans in Late Jurassic time (Carter, Gordon \& Gardner, 2010). If this interpretation is correct, the division of labour in the $D$. aff. ramosus colony might represent the key innovation that led to the much greater diversity and morphological complexity (Bulman, 1970; Rickards, 1975; Crowther \& Rickards, 1977; Bates \& Kirk, 1987, 1991) achieved by graptoloids compared with other pterobranchs.

Acknowledgements. We thank Paul Shepherd for curatorial assistance; Nick Butterfield (Cambridge), Adrian Rushton (Natural History Museum) and Mark Woods (BGS) for reading an earlier draft of this paper; Tony Stebbing, Beth Okamura and Paul Taylor for information on bryozoan parasitology; and the reviewers, who have improved this paper. P. Wilby and M. Howe publish with the permission of the Executive Director, British Geological Survey. This is Cambridge Earth Science contribution number ESC 2556. This research received no specific grant from any funding agency, commercial or not-for-profit sectors.

\section{References}

BATES, D. E. B. 1987. The density of graptoloid skeletal tissue, and its implication for the volume and density of the soft tissue. Lethaia 20, 149-56.

BATES, D. E. B. \& KIRK, N. H. 1987. The role of extrathecal tissue in the construction and functioning of some Ordovician and Silurian retiolitid Graptolites. Bulletin of the Geological Society of Denmark 35, 85-102.

BATES, D. E. B. \& KIRK, N. H. 1991. The ultrastructure, mode of construction and functioning of Ordovician retiolitid graptolites from the Viola Limestone, Oklahoma. Modern Geology 15, 131-286.

Bates, D. E. B. \& Loydell, D. K. 2000. Parasitism on graptoloid graptolites, Palaeontology 43, 1143-51. 
BJERRESKOV, M. 1994 Pyrite diagenesis of graptolites from Bornholm. In Graptolite Research Today (eds X. Chen, B. D. Erdtmann \& Y.-N. Ni), pp. 217-22. Nanjing: Nanjing University Press.

BRIGGS, D. E. G. 2003. The role of decay and mineralization in the preservation of soft-bodied fossils. Annual Review of Earth and Planetary Science 31, 275-301.

BRIGGS, D. E. G. \& KEAR, A. J. 1993. Decay and preservation of polychaetes: taphonomic thresholds in soft-bodied organisms. Palaeobiology 19, 107-35.

Briggs, D. E. G., Kear, A. J., BAAs, M., DE Leeuw, A. J. \& RigBY, S. 1995. Decay and composition of the hemichordate Rhabdopleura: implications for the taphonomy of graptolites. Lethaia 28, 15-23.

BriggS, D. E. G. \& WiLliams, H. S. 1981. The restoration of flattened fossils. Lethaia 15, 157-64.

Bulman, O. M. B. 1944. The Caradoc (Balclatchie) graptolites from limestones in Laggan Burn, Ayrshire. Part I. Monograph of the Palaeontographical Society, London 97, 1-42.

BUlman, O. M. B. 1970. Graptolithina with sections on Enteropneusta and Pterobranchia. In Treatise on Invertebrate Palaeontology, Part V (ed. C. Teichert), pp. 1-101. Boulder, Colorado: Geological Society of America; Lawrence, Kansas: University of Kansas Press.

BULMAN, O. M. B. \& RickARDS, R. B. 1966. A revision of Wiman's dendroid and tuboid graptolites. Bulletin of the Geological Institution of the University of Uppsala 43, $1-73$.

BUtTERFIELD, N. J. 1990. Organic preservation of nonmineralizing organisms and the taphonomy of the Burgess Shale. Paleobiology 16, 272-86.

BUTTERFIELD, N. J. 2003. Exceptional fossil preservation and the Cambrian explosion. Integrative and Comparative Biology 43, 166-77.

CARter, M. C., Gordon, D. P. \& Gardner, J. P. A. 2010. Polymorphism and variation in modular animals: morphometric and density analyses of bryozoan avicularia. Marine Ecology Progress Series 399, 11730.

Chapman, A. J., Durman, P. N. \& Rickards, R. B. 1993. Rhabdopleuran hemichordates: new fossil forms and review. Proceedings of the Geologists' Association 106, 293-303.

CROWTHER, P. R. \& RiCKARDS, R. B. 1977. Cortical bandages and the graptolite zooid. Geologica et Palaeontologica 11, 9-46.

DiLly, P. N. 1972. Some observations on living Rhabdopleura compacta [Hemichordata]. Journal of the Marine Biological Association 52, 443-8.

DiLlY, P. N. 1975. The dormant buds of Rhabdopleura compacta (Hemichordata). Cell and Tissue Research 159, 387-97.

Dilly, P. N. 1993. Cephalodiscus graptolitoides sp. nov., probable extant graptolite. Journal of Zoology 229, 6978.

Donoghue, P. \& Purnell, M. A. 2009. Distinguishing heat from light in debate over controversial fossils. Bioessays 31, 178-89.

DURMAN, P. N. \& SENNIKOV, N. V. 1991. A new rhabdopleurid hemichordate from the Middle Cambrian of Siberia. Palaeontology 36, 283-96.

Elles, G. L. \& Wood, E. M. R. 1901-1918 A Monograph of British Graptolites. London: Palaeontographical Society, i-clxxi, a-m, 1-536.

Hou, X., Aldridge, R. J., Siveter, D. J., Siveter, D. J., Williams, M., ZalasieWICZ, J. \& MA, X. 2011. An
Early Cambrian hemichordate zooid. Current Biology 21, 1-5.

HUTT, J. E. 1974. A new group of Llandovery biform monograptids. In Graptolite Studies in Honour of O.M.B. Bulman (eds R. B. Rickards, D. E. Jackson \& C. P. Hughes), pp. 189-203. Special Papers in Palaeontology no. 13. London: Palaeontological Association.

JACKSON, D. E. 1971. Development of Glyptograptus hudsoni sp. nov. from Southampton Island, North-West Territories, Canada. Palaeontology 14, 478-86.

KoZıOWSKI, R. 1948. Les graptolithes et quelques nouveaux groupes d'animaux du Tremadoc de la Pologne. Acta Palaeontologia Polonica 3, 1-235.

KozŁowsKi, R. 1962. Crustoidea - nouveau groupe de Graptolithes. Acta Palaeontologica Polonica 7, 3-52.

LEGRAND, Ph. 1978. Sur la presence des structures tubulaires a l'interieur des theques de Diplograptus fezzanensis A. Desio. Comptes Rendus de l'Academie des Sciences, Paris, Série D 286, 387-90.

Legrand, Ph. 1979. Premieres observations sur des structures tubulaires a l'interieur des theques de Diplograptus fezzanensis Desio. Essai d'interpretation. In Proceedings of the First International Conference "Advances in graptolite research", 1977. Acta Palaeontologica Polonica 24, 107-20.

LEGRAND, Ph. 1986. New data on tubular structures located within diplograptid rhabdosomes and in the surrounding sediment. Hercynica 2, 11-123.

LOYDELL, D. K., ORR, P. J. \& KEARNS, S. 2004. Preservation of soft tissues in Silurian graptolites from Latvia. Palaeontology 47, 503-13.

Maletz, J., Steiner, M. \& FATKA, O. 2005. Middle Cambrian pterobranchs and the question: what is a graptolite? Lethaia 38, 73-85.

MCKINNEY, F. K. 2009. Bryozoan-hydroid symbiosis and a new ichnogenus, Caupokeras. Ichnos 16, 193-201.

Melchin, M. J. \& DeMonT, M. E. 1995. Propulsion modes in the Graptolidea: a new model for graptolite locomotion. Paleobiology 21, 110-20.

Page, A., GabBott, S. E., Wilby, P. R. \& Zalasiewicz, J. A. 2008. Ubiquitous Burgess Shale-style "clay templates" in low-grade metamorphic mudrocks. Geology 36, $855-8$.

Page, A., Wilby, P. R., Mellish, C. J. T., Williams, M. \& ZAlasiewicz, J. A. 2009 (for 2008). Dawsonia (Nicholson): linguliform brachiopods, crustacean tailpieces and a problematicum rather than graptolite ovarian vesicles. Earth \& Environmental Science Transactions of the Royal Society of Edinburgh 99, 25166.

Page, A., Wilby, P. R., Williams, M., Vannier, J., DaVies, J. R., WATERS, R. \& Zalasiewicz, J. A. 2010. Softpart preservation in a bivalved arthropod from the Late Ordovician of Wales. Geological Magazine 147, 24252.

PALMER, D. \& RICKARDS, R. B. 1991. Graptolites: Writing in the Rocks. Woodbridge, Surrey: Boydell Press, $182 \mathrm{pp}$.

RICKARDS, R. B. 1975. The palaeoecology of the Graptolithina, an extinct class of the phylum Hemichordata. Biological Reviews 50, 397-436.

Rickards, R. B., PARTRIDGE, P. L. \& BANKS, M. R. 1991. Psigraptus jacksoni Rickards and Stait - systematics, reconstruction, distribution and preservation. Alcheringa 15, 243-54.

RIGBY, S. \& SUDBURY, M. 1995. Graptolite ontogeny and the size of the graptolite zooid. Geological Magazine 132, 427-33. 
Rushton, A. W. A. 2001 (for 2000). The use of graptolites in the stratigraphy of the Southern Uplands: Peach's legacy. Transactions of the Royal Society of Edinburgh: Earth Sciences 91, 341-7.

SATO, A. 2008. Seasonal reproductive activity in the pterobranch hemichordate Rhabdopleura compacta. Journal of the Marine Biological Association 88, 1033-41.

SHERWIN, L. \& RICKARDS, B. 2000. Rogercooperia, a new genus of Ordovician glossograptid graptolite from southern Scotland and New South Wales, Australia. Scottish Journal of Geology 36, 159-64.

SteBbinG, A. R. D. 1970. Aspects of the reproduction and life cycle of Rhabdopleura compacta (Hemichordata). Marine Biology 5, 205-12.

SUDBURY, M. 1958. Triangulate monograptids from the Monograptus gregarius Zone (lower Llandovery) of the Rheidol Gorge (Cardiganshire). Philosophical Transactions of the Royal Society of London B281, 485-555.

Sutton, M. D., Briggs, D. E. G., Siveter, D. J. \& Siveter, D. J. 2001. A three-dimensionally preserved fossil polychaete worm from the Silurian of Herefordshire, England. Proceedings of the Royal Society, London B268, 2355-63.

UNDERWOOD, C. J. 1992. Graptolite preservation and deformation. Palaios 7, 178-86.

URBANEK, A. 1962. The significance of graptoblasts in the life cycle of crustoid graptolites. Acta Palaeontologica Polonica 28, 313-26.

URBAneK, A. \& Dilly, P. N. 2000. The stolon system in Rhabdopleura compacta (Hemichordata) and its phylogenetic implications. Acta Palaeontologica Polonica 45, 201-26.

Zalasiewicz, J. A. \& Howe, M. P. A. 2003. A case of profound astogenetic metamorphosis: the structure and affinities of Awarograptus nodifer (Törnquist, 1881). Scottish Journal of Geology 39, 45-9.

Zalasiewicz, J. A., TAYloR, L., Rushton, A. W. A., LOYDELl, D. K., RickARDS, R. B. \& Williams, M. 2009. Graptolites in British stratigraphy. Geological Magazine 146, 785-850. 